\title{
Using Cover Crops to Suppress Horseweed
}

Authored by Kara B. Pittman, Extension Associate, School of Plant and Environmental Sciences, Virginia Tech; and Michael L. Flessner, Assistant Professor and Extension Weed Science Specialist, School of Plant and Environmental Sciences, Virginia Tech

Horseweed (Conyza canadensis), also known as marestail, is a profoundly widespread and problematic weed in Virginia crop production (figure 1). Yield losses reaching $46 \%$ due to horseweed have been reported in cotton with a density of 17 to 21 plants per square yard (Steckel and Gwathmey 2009). Horseweed can produce up to 200,000 seeds per plant. The seeds are winddispersed, allowing for long-distance dissemination between fields and across farms (Andersen 1993; Bhowmik and Bekech 1993). This species is often difficult to control due to herbicide resistance, and concern is increasing because of evidence that it is becoming resistant to several herbicide sites of action (SOA). Currently in Virginia, horseweed is resistant to glyphosate (SOA group 9) and there are likely populations that are resistant to ALS herbicides (SOA group 2) (Virginia Tech, n.d.). In the Mid-Atlantic region, resistance to paraquat (SOA group 22) has also been reported (Heap, n.d.). In soybeans, only a few herbicide options can effectively control horseweed postemergence.
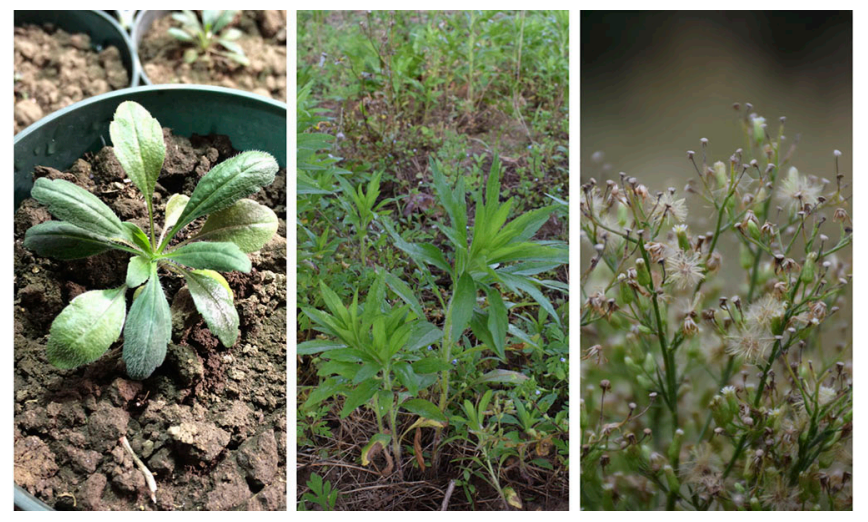

Figure 1. Horseweed across various growth stages. Left to right: rosette, bolt, and flowering.

\section{Cover Crops for Weed Manage- ment}

Horseweed's herbicide resistance is becoming more prevalent, making control more difficult. With that, as well as an increasing desire for more sustainable agricultural practices, cover crops are becoming more popular as a weed management tool. Cover crops have the ability to reduce erosion, increase soil organic matter, introduce new channels to aerate the soil, and suppress weeds.

Winter cover crops suppress weeds at two different times: while the cover crop is actively growing and after the cover crop is terminated. Cover crops that are actively growing will compete with weeds for resources such as sunlight, water, and nutrients. Once terminated, cover crops can create a mulch layer on the soil surface that will block germination cues and provide a physical barrier to weed growth (Mirsky et al. 2013). Small grain or grass cover crop species have higher carbon-to-nitrogen $(\mathrm{C}: \mathrm{N})$ ratios compared with legume and brassica cover crop species. Cover crop residue with a higher $\mathrm{C}: \mathrm{N}$ ratio will break down more slowly, which means that the mulch layer can last longer and extend weed suppression. Cover crop residue with a $\mathrm{C}: \mathrm{N}$ ratio of greater than 30:1 can result in nitrogen immobilization, in which soil organisms use up the nitrogen, making it unavailable to plant life (Herbert et al. 1997). Therefore, some grass cover crops may suppress weeds by $\mathrm{N}$ stress, but they also have potential to stress the cash crop.

Horseweed can germinate in both the fall and spring, which can make control more complicated (Bhowmik and Bekech 1993; Main et al. 2006). Winter cover crops have a unique ability to target both of these germination periods.

Gaining biomass is particularly important when using cover crops to suppress weeds. Greater biomass creates a thicker mulch layer that will take longer to break down, extending the weed suppression period. To do this, it is important to have a healthy stand. Planting the cover crop with a drill is recommended over broadcasting seed. Also, provide time to allow the cover crop to gain as much biomass as possible before termination. Plant earlier or, better yet, delay termination 
to help expand the season and maximize biomass. Research indicates that maximum biomass accumulation for most cover crop species occurs around May 1 in Virginia.

Cover crop species selection is also important. Poor candidates are species that typically winter-kill, such as forage radish, field pea, and spring oats. These species do not survive the winter so there is no additional biomass accumulation in early spring (Virginia NRCS 2015). Typically, cereal rye gains the most biomass and is therefore one of the best cover crop species for weed suppression.

\section{Research Results}

Research trials were conducted in Blacksburg and Blackstone, Virginia, over two years to test how well different cover crop species suppressed horseweed (Pittman et al. 2019). The trials also included two residual herbicides applied in the fall, as well as nontreated areas, to compare those results with the weed suppression provided by cover crops.
Treatments (cover crops or herbicides) and the seeding and application rates are included in table 1 . These treatments were either planted or applied in the fall, approximately late September to mid-October. Horseweed densities were collected in mid-March to assess cover crop suppression of fall-germinating horseweed. Cover crops were terminated by rolling prior to planting either corn or soybean. Six weeks after termination, visible horseweed suppression ratings were taken on a 0 (no suppression) to 100 (complete suppression) scale compared with the nontreated check. Horseweed biomass samples were taken prior to corn or soybean harvest. Cash crop yields were then measured to compare weed suppression effects across treatments.

Across cover crop treatments, cereal rye alone and cereal rye-containing mixtures obtained greater biomasses, 6,800 to 7,200 pounds per acre, compared with the two legume species, crimson clover and hairy vetch, in monoculture, which resulted in a biomass of 3,000 pounds per acre.

Table 1. Cover crop monoculture and mixture seeding rates and herbicide rates used in this study.

\begin{tabular}{|c|c|c|c|c|c|c|}
\hline Treatment & Species 1 & Species 2 & Species 3 & $\begin{array}{c}\text { Species } 1 \\
\text { Seeding Rate }\end{array}$ & $\begin{array}{c}\text { Species } 2 \\
\text { Seeding Rate }\end{array}$ & $\begin{array}{c}\text { Species } 3 \\
\text { Seeding Rate }\end{array}$ \\
\hline & & & & \multicolumn{3}{|c|}{------------------------lbs per acre----------------------- } \\
\hline 1 & Cereal Rye & -- & --- & 112 & -- & --- \\
\hline 2 & Crimson Clover & -- & --- & 20 & --- & --- \\
\hline 3 & Hairy Vetch & -- & --- & 25 & -- & -- \\
\hline 4 & Forage Radish & -- & --- & 8 & -- & --- \\
\hline 5 & Cereal Rye & Crimson Clover & -- & 45 & 14 & -- \\
\hline 6 & Cereal Rye & Hairy Vetch & --- & 45 & 18 & -- \\
\hline 7 & Cereal Rye & Forage Radish & -- & 62 & 4 & --- \\
\hline 8 & Cereal Rye & Forage Radish & Crimson Clover & 34 & 2 & 12 \\
\hline \multirow[t]{3}{*}{9} & Cereal Rye & Forage Radish & Hairy Vetch & 34 & 2 & 15 \\
\hline & $\begin{array}{c}\text { Herbicide } \\
\text { Product }\end{array}$ & $\begin{array}{l}\text { Application } \\
\text { Rate }\end{array}$ & \multicolumn{4}{|c|}{ Herbicide Active Ingredient } \\
\hline & & oz per acre & & & & \\
\hline 10 & Canopy & 3 & \multicolumn{4}{|c|}{ Metribuzin + Chlorimuron-ethyl } \\
\hline 11 & Valor & 3 & \multicolumn{4}{|c|}{ Flumioxazin } \\
\hline \multicolumn{7}{|c|}{ Nontreated check (no cover or herbicide) } \\
\hline
\end{tabular}




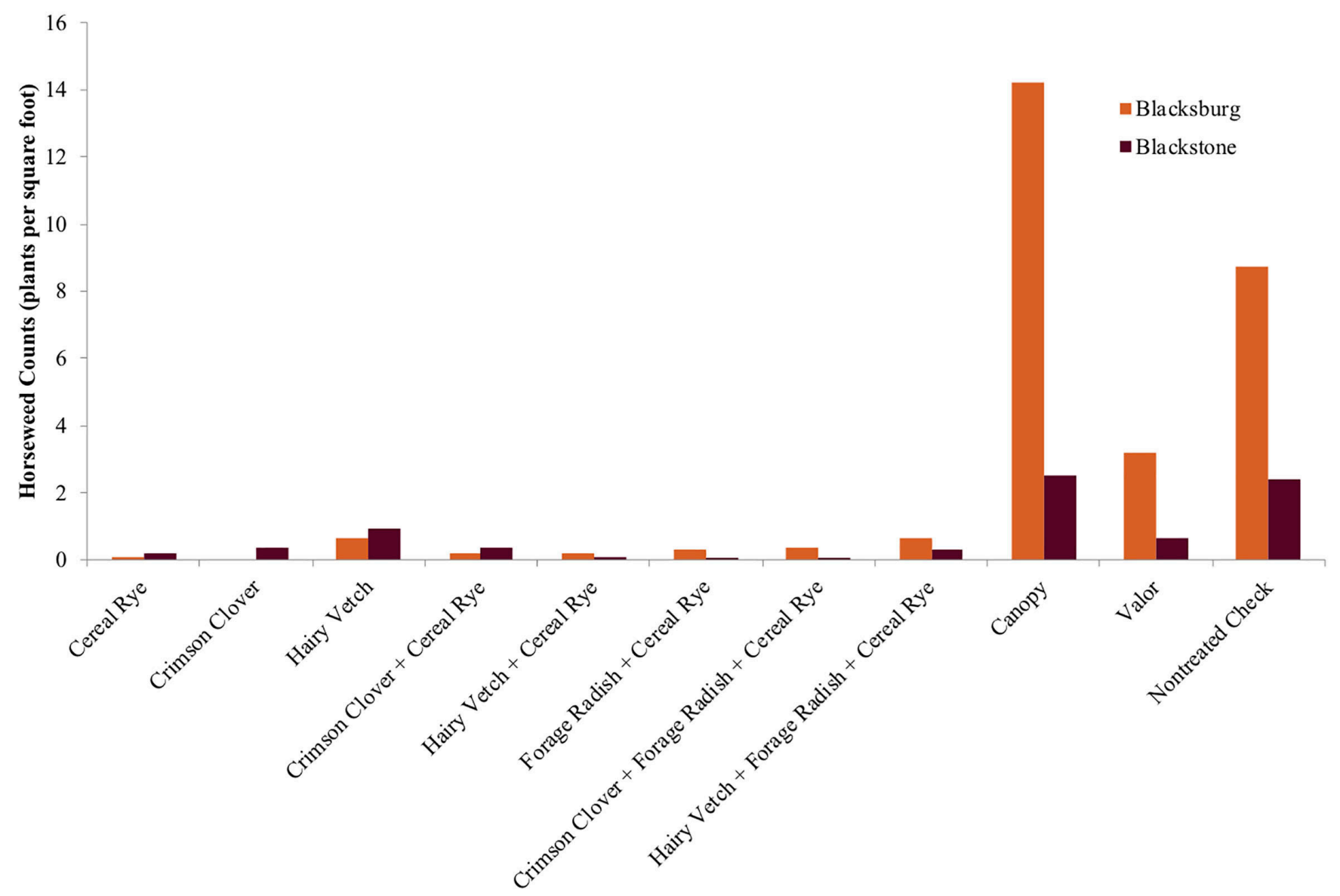

Figure 2. Horseweed counts taken in mid-March show the impact in horseweed density from actively growing cover crops and fall-applied herbicides.

Six weeks after cover crop termination, horseweed suppression was variable, ranging from $55 \%$ to $95 \%$ suppression of horseweed (figure 3). At this point in time, there were no differences in suppression between the cereal rye-containing cover crop treatments and legume monocultures.

This research demonstrates that cover crops can be used as part of a weed management program for horseweed, but cover crops alone will not provide season-long suppression.

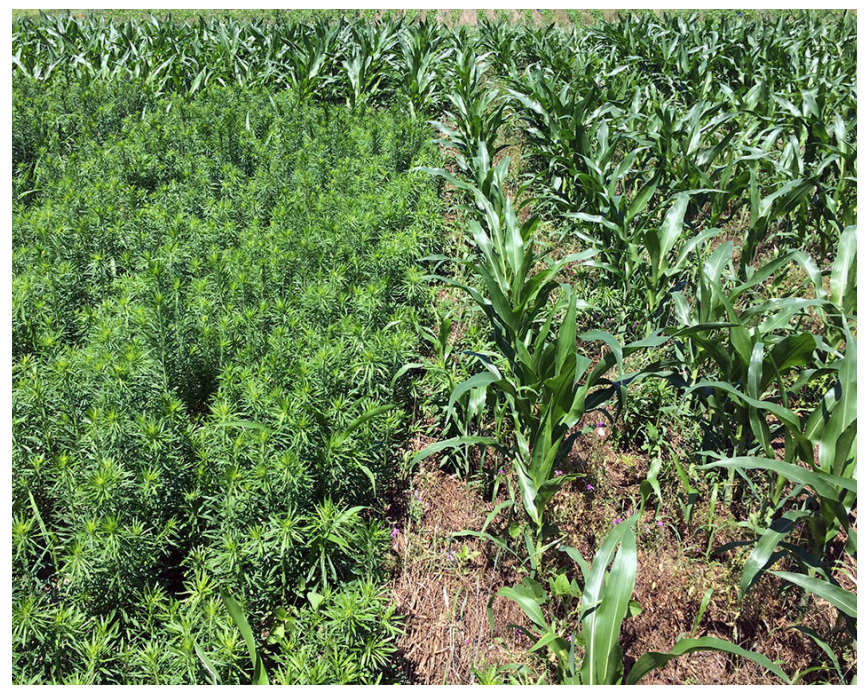

Figure 3. Comparison of horseweed populations between a no-cover crop plot and a cover crop mixture of cereal rye and hairy vetch. 


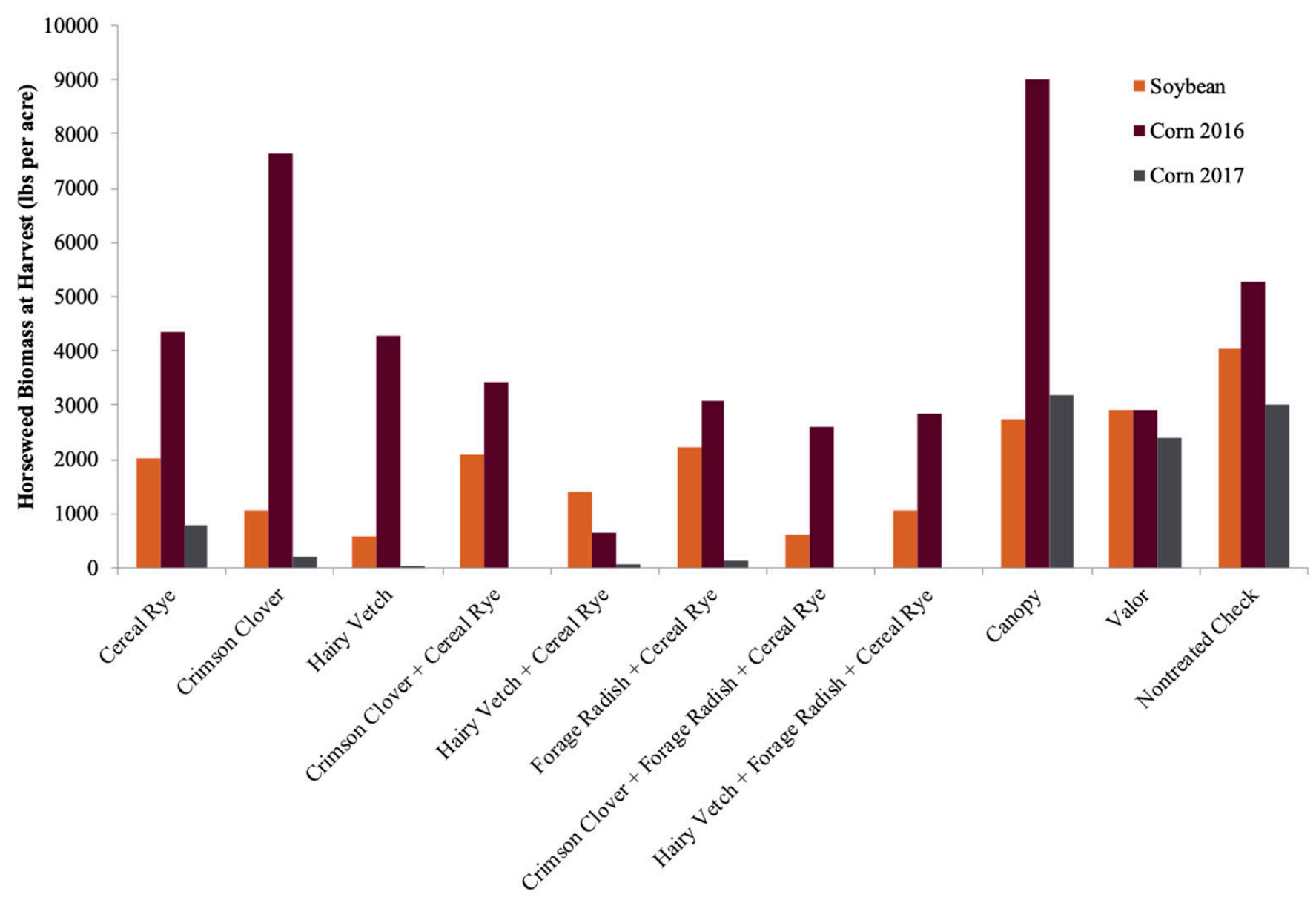

Figure 4. Horseweed biomass collected just prior to corn and soybean harvest. Note that several treatments resulted in zero horseweed biomass in the 2017 corn crop.

Corn yields suffered more from horseweed than soybeans did, although losses in corn were significantly mitigated by the cover crop treatments. With a cover crop treatment, corn plots lost 10.6 bushels per acre from horseweed, while the control plots with no treatment lost 36.7 bushels of corn per acre.

In soybeans, there was no difference in yield loss from horseweed between cover-crop-treated plots and the nontreated check. The cover crops could not suppress horseweed all season long. When the residue would become thin, horseweed plants would emerge and compete with the cash crop. While horseweed did not reduce soybean yield in this experiment, other experiments have observed soybean yield loss due to horseweed competition (Bruce and Kells 1990; Byker et al. 2013).

The fall-applied herbicide treatments, Canopy (metribuzin + chlorimuron) and Valor (flumioxazin), were not as effective at controlling horseweed as the cover crop mixtures. When taking horseweed counts in March, Valor and Canopy performed similarly to the nontreated check. In Blacksburg, where there was more horseweed pressure, using Canopy actually resulted in greater horseweed density than the nontreated check. In this instance, Canopy controlled other winter annual weeds, which reduced competition and allowed horseweed to thrive (figure 5). At six weeks after cover crop termination, Valor suppressed horseweed more than Canopy but neither provided greater suppression than any of the cover crop treatments.

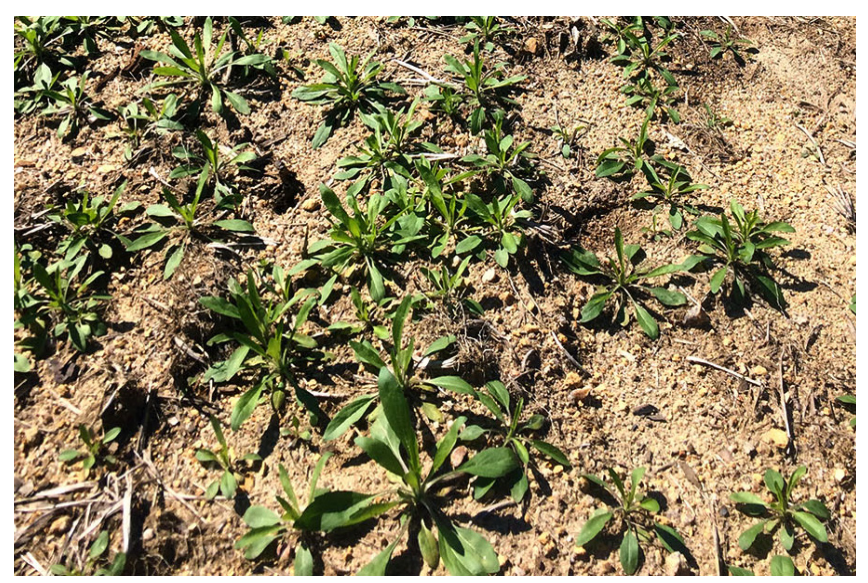

Figure 5. Fall-applied residual herbicides, like Canopy (metribuzin + chlorimuron) shown here, can decrease winter annual weed pressure and reduce the competition for resources allowing horseweed to germinate and grow unchecked. 


\section{Management Implications}

Virginia Tech research shows that cover crops can be used as a weed management tactic to suppress horseweed prior to planting and early in the cropping season. This result, combined with other benefits of cover crops, is substantial. However, cover crops weren't able to provide season-long suppression of horseweed. Once the cover crop mulch degrades, horseweed is able to germinate and grow; therefore, additional weed control methods should be used to control horseweed after this point in the season. It is also important to use an effective burndown herbicide to control horseweed prior to planting. If the opportunity to control horseweed prior to planting a cash crop is missed, control will be more difficult during the growing season.

While cereal rye is often chosen as a cover crop for weed suppression, this research shows that for horseweed, growers could incorporate cereal rye/ legume mixtures or choose legume cover crop species alone. This allows for more flexibility when choosing a cover crop species or mixtures because species can be chosen for other agronomic benefits, such as $\mathrm{N}$ fixation, without sacrificing weed suppression. For any cover crop to suppress weeds, it is important to gain as much biomass as possible through timely planting and proper management.

\section{References}

Andersen, M. C. 1993. "Diaspore Morphology and Seed Dispersal in Several Wind-dispersed Asteraceae." American Journal of Botany 80: 487-492.

Bhowmik, P. C., and M. M. Bekech. 1993. "Horseweed (Conyza canadensis) Seed Production, Emergence, and Distribution in No-tillage and Conventionaltillage Corn (Zea mays)." Agronomy (Trends in Agricultural Science) 1: 67-71.

Bruce, J. A., and J. J. Kells (1990) "Horseweed (Conyza canadensis) control in no-tillage soybeans (Glycine max) with preplant and preemergence herbicides." Weed Technology 4: 642-647.

Byker H. P., N. Soltani, D. E. Robinson, F. J. Tardif, M. B. Lawton, and P. H. Sikkema (2013) "Glyphosateresistant Canada fleabane [Conyza canadensis (L).
Cronq.]: dose response to glyphosate and control with post-emergence herbicides in soybean in Ontario." Canadian Journal of Plant Science 93: 1187-1193.

Heap, I. n.d. The International Herbicide-Resistant Weed Database. Accessed June 27, 2019. http://www. weedscience.org/.

Herbert, S. J., Y. Liu, and G. Liu. 1997. "Decomposition of Cover Crop Biomass and Nitrogen Release." University of Massachusetts Amherst Center for Agriculture, Food and the Environment. https:// ag.umass.edu/research-reports/decomposition-ofcover-crops-biomass-and-nitrogen-release.

Main C. L., L. E. Steckel, R. M. Hayes, and T. C. Mueller. 2006. "Biotic and Abiotic Factors Influence Horseweed Emergence.” Weed Technology 54: 1101-1105.

Mirsky S. B., M. R. Ryan, J. R. Teasdale, W. S. Curran, C. S. Reberg-Horton, J. T. Spargo, M. S. Wells, C. L. Keene, and J. W. Moyer. 2013. "Overcoming Weed Management Challenges in Cover CropBased Organic Rotational No-till Soybean Production in the Eastern United States." Weed Technology 27: 193-203.

Pittman K. B., J. N. Barney, and M. D. Flessner. 2019. "Horseweed (Conyza canadensis) Suppression from Cover Crop Mixtures and Fall-applied Residual Herbicides." Weed Technology 33: 303-311.

Steckel, L. E., and C. O. Gwathmey. 2009. "Glyphosateresistant Horseweed (Conyza canadensis) Growth, Seed Production, and Interference in Cotton." Weed Science 57: 346-350.

Virginia NRCS (Natural Resources Conservation Service). 2015. Virginia NRCS Cover Crop Planning Manual. Virginia Technical Note, Agronomy \#10. https://efotg.sc.egov.usda.gov/references/public/ VA/VA_TN10_Agronomy.pdf.

Virginia Tech. n.d. "Herbicide Resistance in Virginia." Accessed June 27, 2019. https://agweedsci.spes. vt.edu/herbicideresistance.html.

Visit our website: www.ext.vt.edu

Produced by Virginia Cooperative Extension, Virginia Tech, 2020

Virginia Cooperative Extension programs and employment are open to all, regardless of age, color, disability, gender, gender identity, gender expression, national origin, political affiliation, race, religion, sexual orientation, genetic information, veteran status, or any other basis protected by law. An equal opportunity/affirmative action employer. Issued in furtherance of Cooperative Extension work, Virginia Polytechnic Institute and State University, Virginia State University, and the U.S. Department of Agriculture cooperating. Edwin J. Jones, Director, Virginia Cooperative Extension, Virginia Tech, Blacksburg; M. Ray McKinnie, Administrator, 1890 Extension Program, Virginia State University, Petersburg. VT/0520/SPES-164P/SPES-202P 